Article

\title{
An In Vitro Model to Investigate the Role of Helicobacter pylori in Type 2 Diabetes, Obesity, Alzheimer's Disease and Cardiometabolic Disease
}

\author{
Paola Cuomo ${ }^{1,+}+$, , Marina Papaianni ${ }^{1,+}{ }^{\text {, Clementina Sansone }}{ }^{2}$, Antonio Iannelli ${ }^{3,4}$, \\ Domenico Iannelli ${ }^{1, *}$, Chiara Medaglia ${ }^{5}$, Debora Paris ${ }^{6}$, Andrea Motta ${ }^{6}$ (i) \\ and Rosanna Capparelli ${ }^{1, *}$ \\ 1 Department of Agriculture Sciences, University of Naples "Federico II", via Università, 100-Portici, \\ 80055 Naples, Italy; paola.cuomo@unina.it (P.C.); marina.papaianni@unina.it (M.P.) \\ 2 Department of Marine Biotechnology, Stazione Zoologica Anton Dohrn, 80121 Naples, Italy; \\ clementina.sansone@szn.it \\ 3 Department of Digestive Surgery, Université Côte d'Azur, Campus Valrose, Batiment L, Avenue de Valrose, \\ 28-CEDEX 2, 06108 Nice, France; iannelli.a@chu-nice.fr \\ 4 Inserm, U1065, Team 8 "Hepatic Complications of Obesity and Alcohol", Route Saint Antoine de Ginestière \\ 151, BP 2 3194, CEDEX 3, 06204 Nice, France \\ 5 Department of Microbiology and Molecular Medicine, University of Geneva Medical School, \\ rue du Général-Dufour, 1211 Genève, Switzerland; chiara.medaglia@unige.ch \\ 6 Institute of Biomolecular Chemistry, National Research Council, via Campi Flegrei, 34-Pozzuoli, \\ 80078 Naples, Italy; dparis@icb.cnr.it (D.P.); andrea.motta@icb.cnr.it (A.M.) \\ * Correspondence: domenico.iannelli1935@gmail.com (D.I.); capparel@unina.it (R.C.) \\ + These authors contributed equally to this work.
}

Received: 7 October 2020; Accepted: 4 November 2020; Published: 8 November 2020 updates

\begin{abstract}
Helicobacter pylori $(\mathrm{Hp})$ is a Gram-negative bacterium colonizing the human stomach. Nuclear Magnetic Resonance (NMR) analysis of intracellular human gastric carcinoma cells (MKN-28) incubated with the $H p$ cell filtrate (Hpcf) displays high levels of amino acids, including the branched chain amino acids (BCAA) isoleucine, leucine, and valine. Polymerase chain reaction (PCR) Array Technology shows upregulation of mammalian Target Of Rapamycin Complex 1 (mTORC1), inflammation, and mitochondrial dysfunction. The review of literature indicates that these traits are common to type 2 diabetes, obesity, Alzheimer's diseases, and cardiometabolic disease. Here, we demonstrate how $\mathrm{Hp}$ may modulate these traits. $\mathrm{Hp}$ induces high levels of amino acids, which, in turn, activate mTORC1, which is the complex regulating the metabolism of the host. A high level of BCAA and upregulation of mTORC1 are, thus, directly regulated by $\mathrm{Hp}$. Furthermore, $\mathrm{Hp}$ modulates inflammation, which is functional to the persistence of chronic infection and the asymptomatic state of the host. Finally, in order to induce autophagy and sustain bacterial colonization of gastric mucosa, the $\mathrm{Hp}$ toxin VacA localizes within mitochondria, causing fragmentation of these organelles, depletion of ATP, and oxidative stress. In conclusion, our in vitro disease model replicates the main traits common to the above four diseases and shows how $\mathrm{Hp}$ may potentially manipulate them.
\end{abstract}

Keywords: Helicobacter pylori; mTORC1; branched chain amino acids; inflammation; mitochondrial dysfunction

\section{Introduction}

Helicobacter pylori $(\mathrm{Hp})$ is a Gram-negative bacterium colonizing the human gastric mucosa. It is transmitted orally, often within the family. Colonizing about one half of the world's population, 
$H p$, can be classified as one of the most successful human pathogens [1,2]. Genetic diversity and efficient evasion of host innate and adaptive immune responses contribute to this success [3]. Genetic diversity of $\mathrm{Hp}$ originates from a high mutation rate, and is favored by the absence of a DNA mismatch repair mechanism and acquisition of DNA from other strains [3]. The Hp lipopolysaccharide escapes binding by antimicrobial peptides and detection by Tool-like receptors (TLRs) by removing phosphate groups from the lipid A [4]. VacA modulates T-cell proliferation by inhibiting nuclear translocation of the T transcription factor NF-AT [5]. Hp can persist for decades asymptomatically, but carriers are at risk of developing gastritis, duodenal ulcers, non-Hodgkin's lymphoma, or gastric adenocarcinoma. Finally, epidemiological studies suggest that $H p$ may cause extra gastric diseases [6].

Often, bacteria colonize the host by exploiting its metabolism [7]. For this purpose, $\mathrm{Hp}$ uses mTORC1, which is the complex sensing the conditions for cellular survival. mTORC1 is active when nutrients are abundant, and inactive when they are scarce [8]. In the early phase of host colonization, the $\mathrm{Hp}$ toxin VacA inhibits mTORC1 expression and activates autophagy to gain the nutrients needed to colonize the gastric mucosa [9]. Once this phase is terminated, autophagy would obstruct the chronic infection. To prevent this condition, CagA (a toxin antagonistic to VacA) activates mTORC1 [10]. The branched chain amino acids (BCAA) leucine, isoleucine, and valine, together with insulin, actively participate to mTORC1 activation [11]. $\mathrm{Hp}$, through a clever use of two antagonistic toxins, modulates mTORC1 and, consequently, the metabolism of its host. Furthermore, in order to induce autophagy and sustain colonization of gastric mucosa, VacA localizes within the mitochondria by causing mitochondrial DNA mutations in the gastric cells, mitochondrial fragmentation, depletion of ATP, and oxidative stress [12]. Finally, to facilitate chronic infection and persistence of the host asymptomatic state, $\mathrm{Hp}$ modulates inflammation. However, this unstable equilibrium often fails. Inflammation is the most frequent cause of the passage from the asymptomatic state to that of disease [13].

We just described how upregulation of mTORC1, high levels of BCAA, inflammation, and mitochondrial dysfunctions characterize $H p$ infection. According to current literature, the same traits characterize the metabolic diseases known as type 2 diabetes (T2D), obesity (OB), Alzheimer's disease (AD), and cardiometabolic disease (CMD) [14-17]. It seemed, therefore, feasible to investigate whether $H p$ may potentially predispose to the above diseases.

Epidemiological studies have several limitations. They require the enrollment of a large number of patients, and known and unknown confounding factors make results difficult to replicate [18]. Analysis of the cellular metabolic profile of in vitro cultured cells has detected yeast mutants that conventional methods failed to identify [19], while the medium from cultured human muscle cells identified creatine as a biomarker of human mitochondrial disease [20]. Inspired by these results, we tested whether nuclear magnetic resonance (NMR) metabolomics and microarray analysis of the human gastric carcinoma cells MKN-28, incubated for $2 \mathrm{~h}$ with the $\mathrm{Hp}$ cell filtrate (Hpcf), might identify the traits that current literature recognizes as biomarkers of patients with one of the four diseases listed above. MKN-28 incubated with Hpcf showed high levels of BCAA, upregulation of mTORC1, mitochondrial dysfunction, and inflammation. Here, we show that these traits are all referable, at least in part, to $H p$.

\section{Results}

\subsection{NMR-Based Metabolomics Analysis}

The in vitro metabolic effects of $H p c f$ on the MKN-28 cells were investigated by performing NMR-based intracellular and extracellular metabolomics analysis of the MKN-28 cells. Intracellular analysis compared MKN-28 cells incubated and not with the Hpcf of the culture medium used to grow $\mathrm{Hp}$. We first applied the unsupervised Principal Component Analysis (PCA) to verify the homogeneity of samples and then the supervised orthogonal projection to latent structure analysis (OPLS-DA) to 
explore the intracellular metabolic profiles. The score plot (Figure 1A) shows a distinct separation between the two sample classes along the first component $t[1]$.

A

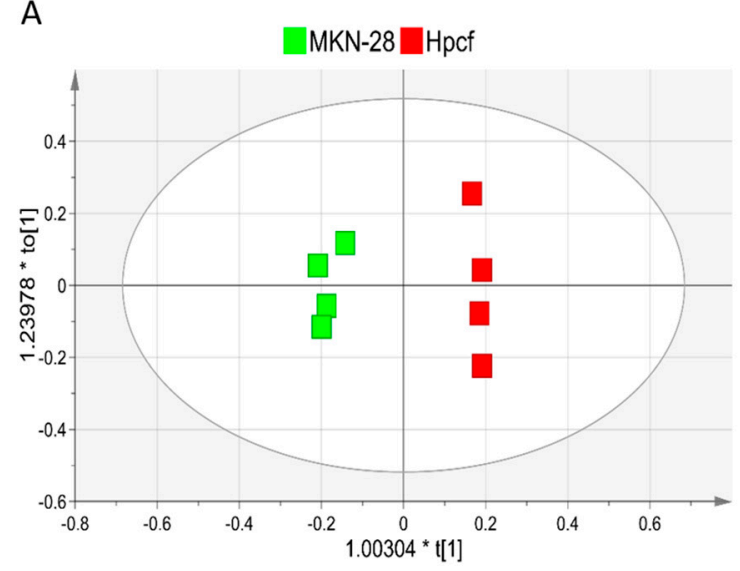

B

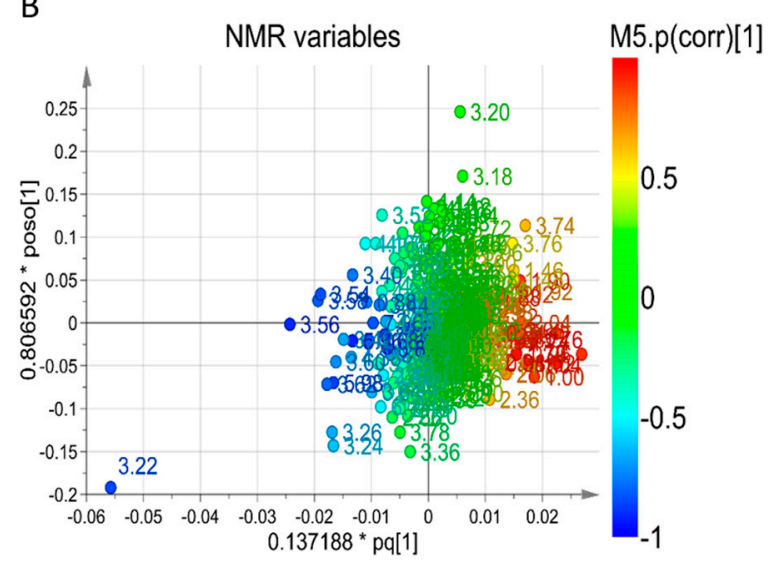

Figure 1. OPLS-DA of MKN-28 cell samples. (A) Scores plot showing the distinct separation between MKN-28 cells incubated (red squares) and not incubated (green squares) with Hpcf. The X-axis title represents the factor multiplied $(*)$ the principal predictive component $\mathrm{t}[1]$ which better approximates the dataset variation correlated with samples classification. On the ordinate axis, the title represents the factor multiplied $\left(^{*}\right)$ the orthogonal component $t[1]$ which accounts for intraclass variation. (B) Loadings plot of nuclear magnetic resonance (NMR) variables (chemical shift) referred to metabolites responsible for between-classes separation and characterized by $\mid p($ corr $) \mid$ value $>0.7$.

In particular, the extracts of $\mathrm{MKN}-28$ cells incubated with $H p c f$ are placed at $\mathrm{t}$ [1] positive coordinates, while the extracts of the MKN-28 cells non-incubated with Hpcf are placed at $t[1]$ negative coordinates. To discriminate between the two groups of samples, we used the NMR loadings plot variables with correlation loading values $\mid p($ corr) $\mid>0.7$ (Figure 1B). Cells incubated with Hpcf when compared with non-incubated cells show higher levels of the amino acids phenylalanine, tyrosine, glutamate, proline, leucine, alanine, valine, and isoleucine, the short chain fatty acids acetate and propionate, saturated fatty acids, sialic acid, and lower levels of taurine (Figures 2A and 3A,B).
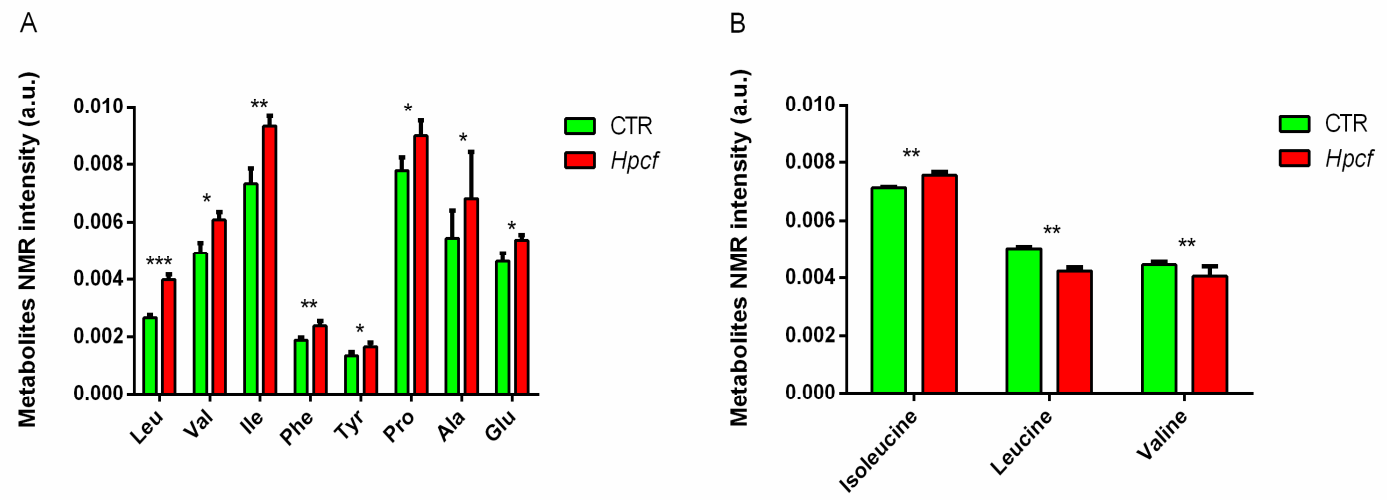

Figure 2. (A) Intracellular amino acid concentration differences (leucine, valine, isoleucine, phenylalanine, tyrosine, proline, and alanine) detected in MKN-28 cells incubated (red columns) or not incubated (green columns) with Hpcf. (B) Extracellular BCAA (leucine, isoleucine, and valine) concentration differences detected in culture medium of MKN-28 cells incubated (red columns) or not incubated (green columns) with Hpcf. Some Hp strains synthesizes isoleucine. Our strain is one of the strains that justify its upregulation. The $\mathrm{X}$-axis reports a single amino acid and the $\mathrm{Y}$-axis reports the bucket variation corresponding to the specific amino acid scaled to the total NMR spectral area. Intensity of amino acids is expressed in arbitrary units and represented as means $\pm \mathrm{SD}\left({ }^{*} p<0.5\right.$, $\left.{ }^{* *} p<0.01,{ }^{* * *} p<0.001\right)$ calculated from two experiments in which each is performed in quadruplicate. 

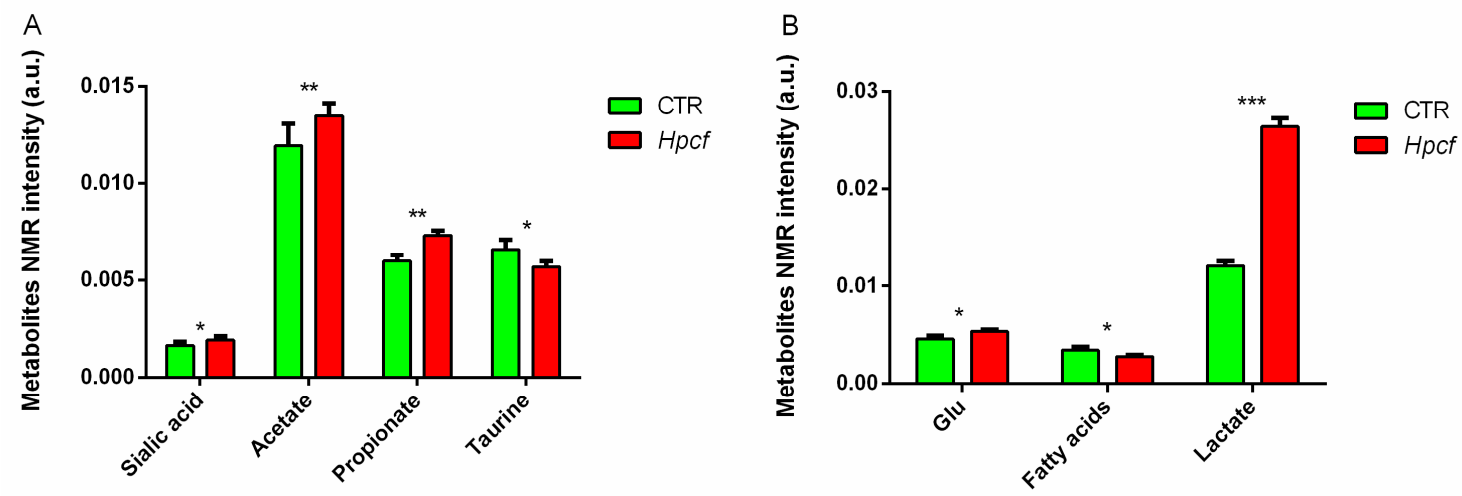

Figure 3. (A) Metabolite concentration differences (sialic acid, acetate, propionate, and taurine) detected in MKN-28 cells incubated (red columns) or not incubated with H. pylori cell filtrate (Hpcf). (B) Metabolite concentration differences (glutamate, fatty acids, and lactate) detected in MKN-28 cells incubated (red columns) or not incubated with H. pylori cell filtrate (Hpcf). The X-axis reports a single metabolite and the $\mathrm{Y}$-axis reports the bucket variation corresponding to the specific metabolite scaled to the total NMR spectral area. Intensity of metabolites is expressed as arbitrary units and represented as means $\pm \mathrm{SD}\left({ }^{*} p<0.5,{ }^{* *} p<0.01,{ }^{* * *} p<0.001\right)$ calculated from two experiments with each performed in quadruplicate.

\subsection{Helicobacter Pylori Alters the Amino Acids Metabolism}

The literature describes a study where two independent cohorts with each consisting of more than 3000 normoglycemic participants being followed for 12 years. High plasma levels of BCAA, and of the two aromatic amino acids (AAA) tyrosine and phenylalanine (out of 60 metabolites) could predict the development of T2D in the enrolled participants as early as 12 years in advance from the onset of the disease [21]. Numerous independent studies confirm the association of high plasma levels of BCAA with T2D [22] and OB [23].

Incubated with $\mathrm{Hpcf}$ for $2 \mathrm{~h}$, the human MKN-28 gastric cells show altered expression levels of 13 metabolites (Figures $2 \mathrm{~A}$ and $3 \mathrm{~A}, \mathrm{~B}$ ) including the five amino acids listed above, which are all expressed at high levels (Figure 2A). These findings, obtained using cells cultured in vitro, replicate the results of the studies carried out on humans and cited above. Furthermore, a recent longitudinal study carried out on a large Japanese population demonstrates that, in addition to the above amino acids, alanine and proline, which are positively associated with visceral fat deposition, while glycine is negatively associated [24]. Our study replicates these results (Figure 2A). The probability that seven out of the 20 (0.35) amino acids upregulated in the studies reported above, and, in the present one, are instead upregulated by chance at $8 \times 10^{-8}$.

Mammals lack the enzymes needed for the synthesis of BCAA [14]. The increased plasma levels of BCAA detected in patients with T2D or OB may result from two potential mechanisms. One claims that an excess of dietary BCAA activates the mTORC1 complex. The alternative mechanism suggests that high levels of BCAA alter the metabolism by causing mitochondrial dysfunction of pancreatic islet $\beta$ cells [22]. MKN-28 cells incubated with Hpcf display upregulation of mTORC1 and mitochondrial dysfunction (Table 1). Therefore, these data indicate that cell culture may fruitfully be used to investigate whether $H p$ influences apparently different diseases. Zucker-obese rats display lower muscle glycine levels compared to Zucker-lean rats. However, when Zucker-obese rats are fed on a BCAA-restricted diet, their muscle glycine levels become normal. These results argue that BCAA metabolism may somehow interfere with that of glycine and, at the same time, give plausibility to the negative association of glycine with BCAA reported above. 
Table 1. Genes of mammalian Target Of Rapamycin (mTOR) signaling, inflammatory, and oxidative stress pathways detected by polymerase chain reaction (PCR) array technology and differently expressed in MKN-28 cells incubated with Hpcf for 1 or $2 \mathrm{~h}$. Variation of gene expression levels is reported as fold regulation. Values $>|2|$ are considered statistically significant.

\begin{tabular}{|c|c|c|c|c|}
\hline $\begin{array}{l}\text { Pathway } \\
\text { Name }\end{array}$ & Gene ID & Gene Name & $\begin{array}{l}\text { Fold Regulation } \\
\qquad 1 \mathrm{~h}\end{array}$ & $\begin{array}{l}\text { Fold Regulation } \\
\qquad 2 \mathrm{~h}\end{array}$ \\
\hline \multirow{15}{*}{$\begin{array}{c}\text { mTOR } \\
\text { signaling } \\
\text { pathway }\end{array}$} & RPTOR & $\begin{array}{l}\text { Regulatory associated protein of mTOR } \\
\text { complex } 1\end{array}$ & -1.42 & 286.04 \\
\hline & MLST8 & $\begin{array}{l}\text { mTOR associated protein, LST8 homolog } \\
\text { (S. cerevisiae) }\end{array}$ & -1.42 & 398.95 \\
\hline & $A K T 1$ & $\begin{array}{l}\text { V-akt murine thymoma viral oncogene } \\
\text { homolog } 1\end{array}$ & -1.42 & 50.13 \\
\hline & $A K T 2$ & $\begin{array}{l}\text { V-akt murine thymoma viral oncogene } \\
\text { homolog } 2\end{array}$ & -1.42 & 504.97 \\
\hline & INSR & Insulin receptor & -1.42 & 257.79 \\
\hline & IRS1 & Insulin receptor substrate 1 & -1.42 & 278.22 \\
\hline & PLD1 & $\begin{array}{c}\text { Phospholipase D1, } \\
\text { phosphatidylcholine-specific }\end{array}$ & -6.31 & 130.70 \\
\hline & RPS6KA2 & $\begin{array}{l}\text { Ribosomal protein S6 kinase, } 90 \mathrm{kDa} \text {, } \\
\text { polypeptide } 2\end{array}$ & -1.24 & 3.37 \\
\hline & PDPK1 & $\begin{array}{l}\text { 3-phosphoinositide dependent protein } \\
\text { kinase-1 }\end{array}$ & -1.53 & 28.25 \\
\hline & PIKЗСВ & $\begin{array}{l}\text { Phosphoinositide-3-kinase, catalytic, } \\
\text { beta polypeptide }\end{array}$ & -1.42 & 16.34 \\
\hline & PIK3CD & $\begin{array}{l}\text { Phosphoinositide-3-kinase, catalytic, } \\
\text { delta polypeptide }\end{array}$ & 3.37 & 184.83 \\
\hline & PIK3CG & $\begin{array}{l}\text { Phosphoinositide-3-kinase, catalytic, } \\
\text { gamma polypeptide }\end{array}$ & -1.42 & 215.28 \\
\hline & СНUК & $\begin{array}{l}\text { Conserved helix-loop-helix ubiquitous } \\
\text { kinase }\end{array}$ & -4.08 & 181.03 \\
\hline & EIF4E & Eukaryotic translation initiation factor $4 \mathrm{E}$ & -1.42 & 922.92 \\
\hline & HIF1A & Hypoxia inducible factor 1 , alpha subunit & 192.93 & 955.47 \\
\hline \multirow{5}{*}{$\begin{array}{l}\text { Inflammatory } \\
\text { pathway }\end{array}$} & CXCL8 & Interleukin 8 & -3.29 & 2.96 \\
\hline & $I L-6$ & Interleukin 6 & 14.45 & 114.56 \\
\hline & $T L R 2$ & Toll-like receptor 2 & 58 & 72.18 \\
\hline & TLR9 & Toll-like receptor 9 & 3.29 & 134.55 \\
\hline & TNF & Tumor necrosis factor & 12.9 & 154.26 \\
\hline \multirow{7}{*}{$\begin{array}{l}\text { Oxidative } \\
\text { stress } \\
\text { pathway }\end{array}$} & ATOX1 & $\begin{array}{c}\text { ATX1 antioxidant protein } 1 \text { homolog } \\
\text { (yeast) }\end{array}$ & 3.57 & 37.69 \\
\hline & GPX2 & $\begin{array}{c}\text { Glutathione peroxidase } 2 \\
\text { (gastrointestinal) }\end{array}$ & 3.57 & 37.69 \\
\hline & GPX4 & $\begin{array}{l}\text { Glutathione peroxidase } 4 \\
\text { (gastrointestinal) }\end{array}$ & 3.57 & 37.69 \\
\hline & GSS & Glutathione synthetase & 3.57 & 9.54 \\
\hline & NOX5 & $\begin{array}{l}\text { NADPH oxidase. EF-hand calcium } \\
\text { binding domain } 5\end{array}$ & 3.57 & 7.54 \\
\hline & SOD1 & Superoxide dismutase 1. soluble & -28.68 & -9.67 \\
\hline & SOD2 & Superoxide dismutase 2 . mitochondrial & 3.96 & 4.04 \\
\hline
\end{tabular}


BCAA and glutamate are the two pathways more often altered in patients with AD [25]. High levels of isoleucine are associated with $\mathrm{AD}$ and high levels of valine are associated with reduced risk of AD. The latter result has been confirmed in the longitudinal Rotterdam study [26]. BCAA cross the blood-brain barrier through the large neutral amino acid transporter LAT1 in competition with AAA [27]. When the plasma level of BCAA is chronically elevated, BCAA uptake in the brain is favored at the expense of tryptophan, which is the precursor of serotonin and a molecule with multiple functions. It reduces amyloid- $\beta(\mathrm{A} \beta)$ production (the hallmark of $\mathrm{AD}$ ), protects neural survival, and stabilizes the mood [28]. Furthermore, the enzyme-branched chain amino acid transaminase (BCAT) converts BCAA to glutamate. Heightened levels of glutamate cause neuronal death by excitotoxicity (nerve cells death by glutamate overactivation). Finally, mTORC1 activation and mitochondrial dysfunction have a role in $\mathrm{AD}$. The former enhances the tau-induced neurodegeneration, and apoptosis of post-mitotic neurons while the latter provokes $A \beta$ plaque formation [29]. In conclusion, high levels of isoleucine, valine, and glutamate (Figure 2A), mTORC1 activation (Table 1), and mitochondrial dysfunction (Table 1) reported in this study successfully recapitulate in vitro what is described in human studies. Of note, the convergent dysmetabolism (high levels of isoleucine, valine, and glutamate) common to T2D, $\mathrm{OB}$, and $\mathrm{AD}$ is confirmed by the efficacy in $\mathrm{AD}$ patients of drugs used to treat $\mathrm{T} 2 \mathrm{D}$ and other metabolic diseases [14].

In addition to $\mathrm{T} 2 \mathrm{D}, \mathrm{OB}$, and $\mathrm{AD}$, recently high levels of $\mathrm{BCAA}$ have also been shown to have a critical role in the pathogenesis of heart failure [15]. Studies in a mouse model have demonstrated that accumulation of BCAA requires inhibition of the BCAA-degradation-gene Kruppel-like factor 15 (KLF15). The subsequent intra-myocardial accumulation of BCAA upregulates mTORC1 that activates protein synthesis, cardiac hypertrophy, and heart failure. In a mouse model, pharmacologically induced BCAA catabolism significantly re-establishes the cardiac function [30]. Significantly, suppression of BCAA catabolism and accumulation of BCAA have also been observed in humans with heart failure. With regard to mitochondrial function, accumulation of lipids in the heart and hyperglycemia lead to impaired mitochondrial phosphorylation [31].

\subsection{MKN-28 Cells Uptake BCAA from Culture Medium}

The four diseases listed above have high levels of BCAA as a common feature. Mammalian cells as well as $H p$ cannot synthesize essential amino acids (which include BCAA). To shed light on the origin of the high levels of BCAAs observed in our experiments, we tested the hypothesis that they may derive from the depletion of culture medium by the MKN-28 cells. Following incubation with $H p c f$, the MKN-28 cells display increased concentration of BCAA, while the extracellular medium shows reduced concentration of BCAA (Figure 2A,B). Since both $H p$ and MKN-28 cells are auxotrophic for essential amino acids, the above interpretation seems plausible.

\subsection{Helicobacter Pylori Induces Inflammation and Oxidative Stress}

$H p$ infection induces inflammation via activation of $N F-k B$. In our study, cell inflammation is confirmed by the upregulation of the IL-8, TNF- $\alpha, I l-6, T L R 2$, and TLR9 genes expressed by the MKN-28 cells incubated with Hpcf (Table 1). These cytokines characterize Hp infection and are part of a panel validated to detect inflammation in patients with chronic diseases [32]. If not controlled, inflammation may damage the gastric cells. In our study, we find several metabolites controlling the inflammation triggered by $\mathrm{Hp}$. Taurine curbs the excess of Reactive oxygen species (ROS) produced by mitochondria [33]. The reduced level of this metabolite (Figure 3A) may indicate that part of it has been used to control the high levels of ROS produced by the mitochondria. One more signature in the same direction is sialic acid, expressed at a high level (Figure 3A). This metabolite assists the immune system to discriminate between the self and non-self [34]. Inflammation is also regulated by intracellular (acetate and propionate) and the extracellular (lactate) metabolites (Figure 3A,B). Acetate and propionate modulate the gastric mucosa inflammation [35]. Lactate, the product of the 
catabolism of glucose under anaerobic conditions, induces expression of anti-inflammatory genes, and promotes macrophage polarization [36].

High levels of BCAAs (Figure 2A) and FA (Figure 3B) cause accumulation of catabolic intermediates (propionyl $\mathrm{CoA}$ and succinyl $\mathrm{CoA}$ ) and incompletely oxidized FA contribute to the mitochondrial stress [37]. PCR array technology displayed upregulation of the main genes involved in the cell oxidative stress (Table 1). In particular, upregulation of SOD2, and downregulation of SOD1, point out the involvement of mitochondria in the production of ROS (Figure 4). Mitochondrial dysfunction is further confirmed by the high level of glutamate, which is tightly correlated with mitochondrial stress [35] (Figure 3B).

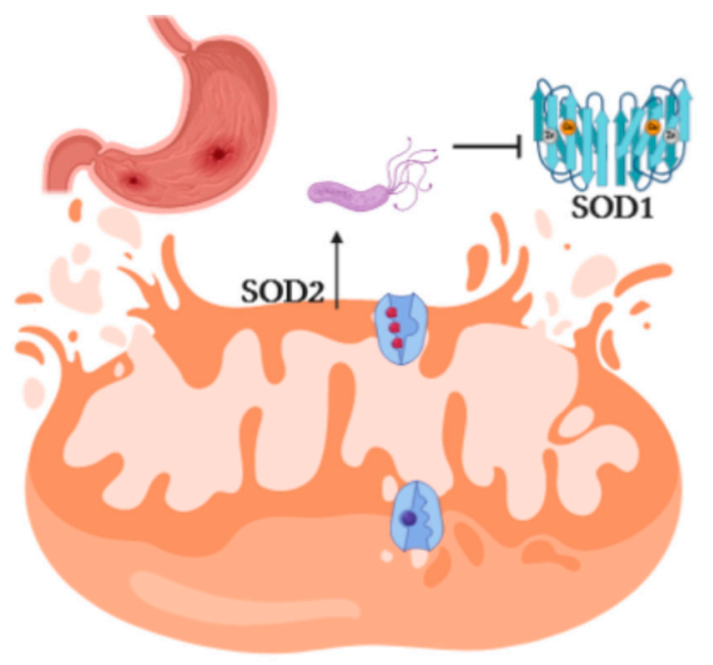

Figure 4. Schematic representation of superoxide dismutase 1 (SOD1) and superoxide dismutase 2 (SOD2) genes modulated by Hp. Downregulation of SOD1 and upregulation of SOD2 point out the involvement of mitochondria in ROS production.

BCAA are required for the activation of mTORC1 [38]. PCR array technology showed up-regulation of both the RPTOR and MLST8 subunits of mTORC1 after $2 \mathrm{~h}$ of Hpcf treatment, with key genes implicated in the regulation of the mTORC1 (AKT1, AKT2, INSR, IRS1, PLD1, and RPS6KA2) being significantly up-regulated ( $p$-value $\leq 0.0001)$. Significantly, upregulated genes include $A K T 1$-involved in the inhibition of protein breakdown-and INSR-sensing the concentration of insulin outside the cell and transmits this signal through the PI3K/Akt/mTORC1 pathway [39]. Finally, mTORC1 activation is confirmed by the overexpression of the positive effectors CHUK, EIF4E, and HIF1A (Table 1).

We can conclude that high levels of BCAA (Figure 2A), activation of mTORC1, impaired mitochondrial activity, and inflammation (Table 1) are dominant traits common to the four diseases under investigation, and all potentially referable to $\mathrm{Hp}$.

\section{Discussion}

Cellular homeostasis is heavily dependent upon a balanced regulation of mTORC1. Thus, deregulation of this complex inevitably leads to many diseases, including metabolic diseases. Though mTORC1 can be modulated by several factors, amino acids are condition necessary and sufficient for promoting cellular anabolic metabolism and mTORC1 activation [40]. Upon incubation with Hpcf, MKN-28 cells show high levels of amino acids (Figure 2A). This result, also observed in the AGS human cell line, reflects the demand of nutrients by $H p$ [41]. At the same time, it displays the tight connection linking mTORC1 activation, high amino acids concentrations, and Hp infection.

In the absence of inflammation, immune cells exploit an anabolic metabolism modulated by mTORC1 tempered by $c-M Y C$. In the presence of inflammation, $c-M Y C$ is suppressed and mTORC1 moves under the control of HIF1 $\alpha$ [42]. This finding indicates that cell replication and inflammation both 
depend upon mTORC1, but are regulated by $c-M Y C$ in the absence of inflammation and H1F1 $\alpha$ in the presence of inflammation. In addition of inducing anabolic metabolism, inflammation inhibits $A M P K$, which is the activator of catabolic metabolism [43]. In our study, upregulation of HIF1 $\alpha$ and mTORC1 indicates that MKN-28 cells, upon incubation with $H p c f$, express the mTORC1-HIF1 $\alpha$-regulated inflammatory phenotype (Table 1). Induction of TNF- $\alpha$ and IL-6 (Table 1) confirms the suppression of $A M P K$, which is a condition required for expression of these cytokines. Enhanced glycolysis via activation of PIK3 subunits and mTORC1-HIF1 $\alpha$ (Table 1) and suppression of AMPK further confirm the anabolic state of the MKN-28 cells. Activation of MKN-28 cells by Hpcf and expression of the genes modulating mTORC1-HIF1 $\alpha$ are one more proof of the tight connection between $H p$ and mTORC1 activation.

As a supervisor of host cell nourishment, mTORC1 is also the target of bacteria. To establish infection, bacteria often need to shift the host cellular metabolism from anabolic to catabolic. Inhibition of mTORC1 by the $\mathrm{Hp}$ toxin VacA is interpreted as a means used by the bacterium to prevent the production of nutrients needed by immune cells of the host to mount an antibacterial response [12]. Taken alone, inhibition of mTORC1 by VacA may seem at odds with the activation of the same gene by increased concentrations of amino acids. Actually, $\mathrm{Hp}$ has adopted this strategy to better exploit the resources of the host. Autophagy induced by the VacA toxin is useful to $H p$ during the gastric mucosa colonization phase [44]. However, once $H p$ has colonized the gastric mucosa, autophagy becomes harmful for the survival of bacteria. Therefore, in this phase of infection, VacA is neutralized by CagA [10]. Two virulence factors of $H p$, acting antagonistically, protect the survival of bacteria during different phases of the infection: a highly rewarding result for $\mathrm{Hp}$ that, by the same mechanism, can inhibit or activate the host cellular metabolism.

$H p$ directly impacts on mitochondria and inflammation. Mitochondria are involved in ATP production, apoptosis, lipid, and amino acids metabolism [45]. In our in vitro experiment, the signatures of mitochondrial stress are evident as upregulation of the antioxidant superoxide dismutase SOD2 (Table 1) and those of inflammation as secretion of the pro-inflammatory factors as well as TNF- $\alpha$ and IL-6 genes (Table 1). At this stage, we can conclude that the traits common to the four diseases can all be associated, at least in part, with $\mathrm{Hp}$.

Several interesting insights emerge from this study. First, it demonstrates that cell lines can be used successfully to investigate genetic or metabolic disorders. Cell line experiments, compared to studies on patients, offer the advantage of reducing variables, differences in the diet, use of drugs, or genetic heterogeneity, between participants. Second, the study raises the question whether a concerted effort to study the basic biology of diseases with several traits in common (as T2D, OB, AD, and CMT) may be more effective than the traditional approach of studying each disease separately. Third, here, we point out that $\mathrm{Hp}$ and mammals have lost the genes coding for essential amino acids. Evolution gives some hints about the benefits associated with gene loss [46]. Organisms, bacteria as well as mammals, evolve under changing environmental conditions. If amino acids are available in the environment, the corresponding genes, no longer adaptive, are lost or undergo mutations leading to more adaptive genes. Following this logic, it seems clear that mammals and $\mathrm{Hp}$ are auxotrophic for essential amino acids. Mammals can obtain essential amino acids from their diet. Hp finds them in its niche (the gastric mucosa), which is rich in essential amino acids derived from the diet of the host [7].

Finally, we acknowledge a limit of this study. We describe four traits common to the four diseases and $H p$ infection. However, this finding is not sufficient to attribute to $H p$ a causal role for the above diseases. Hp could just be the biomarker of a genetic or metabolic disorder carried by the MKN-28 cell line. It is hard to distinguish between causation and association, especially in the case of highly complex diseases. Despite the fact that high levels of BCAA anticipate of many years T2D, it is not known yet whether BCAA are the cause of T2D or a biomarker of insulin resistance [11]. However, human stem cells-derived organoids [47] from healthy donors and from patients with the above diseases may permit us to repeat the study in a known genetic context and clarify the role of $H p$. 


\section{Materials and Methods}

\subsection{Helicobacter Pylori}

Hp strain ATCC 43504 was grown in Brain Heart Infusion medium (BHI, Oxoid, UK) complemented with 10\% Fetal Bovine Serum (FBS, Oxoid, UK) and incubated under microaerophilic condition at $37^{\circ} \mathrm{C}[48]$.

\subsection{Cell Culture Conditions}

The human gastric adenocarcinoma MKN-28 cell lin00000000000e (ATCC, MD, USA) was grown in DMEM/F12 medium, supplemented with 10\% FBS, 1\% penicillin/streptomycin, and 1\% glutamine in a $100-\mathrm{mm}$ culture dish at $37^{\circ} \mathrm{C}$ in a $5 \% \mathrm{CO}_{2}$ atmosphere. The reagents were all from Gibco, ThermoFisher, Waltham, MA, USA.

\subsection{Cell Culture for Metabolomics Analysis}

Confluent 100-mm dishes were incubated for two hours with Hpcf, or as a control with BHI medium. The cells were detached from the adherent substrate with trypsin (1.5 $\mathrm{mL}$ for $3 \mathrm{~min})$, and washed twice with Phosphate-Buffered Saline (PBS). The mixture, containing detached cells, was transferred into a Falcon tube and centrifuged at $1200 \mathrm{rpm}$ and $25^{\circ} \mathrm{C}$ for $3 \mathrm{~min}$. The liquid phase was discarded, and the cell pellet was washed three times with $5 \mathrm{~mL}$ of PBS. After the last wash, the cell pellet was frozen in liquid nitrogen and stored at $-80{ }^{\circ} \mathrm{C}$ until metabolites extraction.

\subsection{Metabolites Extraction and NMR Samples Preparation}

Combined extraction of polar and hydrophobic metabolites was carried out by using ice-cold methanol/Milli-Q ${ }^{\circledR}$ water/chloroform (1/0.72/1) solvents as described by Papaianni et al. 2020 [49]. NMR-based intracellular metabolomics analysis and NMR-based extracellular metabolomics analysis were shown as Papaianni et al., 2020 [50].

\subsection{NMR Spectroscopy}

NMR spectra were recorded on a Bruker Avance III-600 MHz spectrometer (Bruker BioSpin GmbH, Rheinstetten, Germany) as reported [51].

\subsection{RNA Extraction and Real-Time PCR}

Gene expression analysis through PCR array technology was performed as described [52]. Briefly, cells $\left(2 \times 10^{6}\right)$, used for RNA extraction, were seeded in Petri dishes (100 mm diameter) and treated with Hpcf. After $2 \mathrm{~h}$ of exposure time, cells were washed directly in the Petri dish by adding cold PBS. Cells were lysed in the Petri dish by adding $1 \mathrm{~mL}$ of Trisure Reagent (Bioline, Memphis, TN, USA). RNA was isolated according to the manufacturer's protocol. RNA concentration and purity were assessed using the nanophotomer NanodroP (Euroclone, Milan, Italy). RNA (200 ng) was reverse transcribed using the RT2 first strand kit (Qiagen, Hilden, Germany), according to the manufacturer's instructions. The qRT-PCR analysis was performed in triplicate using the RT2 Profiler PCR Array kit (Qiagen, Hilden, Germany). Plates were run on a ViiA7 (Applied Biosystems, Foster City, CA, USA) according to the Standard Fast PCR Cycling protocol with $10 \mu \mathrm{L}$ reaction volumes. Cycling conditions were: 1 cycle initiation at $95.0^{\circ} \mathrm{C}$ for $10 \mathrm{~min}$, which was followed by amplification for 40 cycles at $95.0^{\circ} \mathrm{C}$ for $15 \mathrm{~s}$ and $60.0^{\circ} \mathrm{C}$ for $1 \mathrm{~min}$. Amplification data were collected via ViiA 7 RUO Software (Applied Biosystems, Foster City, CA, USA). The cycle threshold (Ct)-values were analysed with PCR array data analysis online software (http://pcrdataanalysis.sabiosciences.com/pcr/arrayanalysis.php, Qiagen, Hilden, Germany). 
Author Contributions: R.C., D.I., A.I., C.M., P.C., and M.P. designed the research. P.C., M.P., and C.S. performed the research. A.M., D.P. analyzed metabolic data. D.I. and R.C. wrote the paper. All authors have read and agreed to the published version of the manuscript.

Funding: The authors declare no competing financial interest.

Acknowledgments: We thank anonymous reviewers for insightful suggestions that clearly improved the quality of the article.

Conflicts of Interest: The authors declare no conflict of interest.

$\begin{array}{ll}\text { Abbreviations } \\ \text { Hp } & \text { Helicobacter pylori } \\ \text { NMR } & \text { Nuclear Magnetic Resonance } \\ \text { Hpcf } & \text { Hp cell filtrate } \\ \text { BCAA } & \text { Branched chain amino acids } \\ \text { mTORC1 } & \text { mammalian Target Of Rapamycin Complex 1 } \\ \text { TLRs } & \text { Tool like receptors } \\ \text { NF-AT } & \text { nuclear translocation of the T transcription factor } \\ \text { T2D } & \text { Type 2 diabetes } \\ \text { OB } & \text { Obesity } \\ \text { AD } & \text { Alzheimer's disease } \\ \text { CMD } & \text { Cardiometabolic disease } \\ \text { PCA } & \text { Principal Component Analysis } \\ \text { OPLS- } & \text { Orthogonal partial least squares discriminant analysis } \\ \text { AAA } & \text { Aromatic amino acids } \\ \text { ROS } & \text { Reactive oxygen species } \\ \text { LAT1 } & \text { Large neutral amino acid transporter } \\ \text { BCAT } & \text { Branched chain amino acid transaminase } \\ \text { KLF15 } & \text { Kruppel-like factor 15 } \\ \text { FBS } & \text { Fetal Bovine Serum } \\ \text { BHI } & \text { Brain Heart Infusion medium } \\ \text { PBS } & \text { Phosphate-Buffered Saline }\end{array}$

\section{References}

1. Salama, N.R.; Hartung, M.L.; Müller, A. Life in the human stomach: Persistence strategies of the bacterial pathogen Helicobacter pylori. Nat. Rev. Microbiol. 2013, 11, 385-399. [CrossRef]

2. Cuomo, P.; Papaianni, M.; Fulgione, A.; Guerra, F.; Capparelli, R.; Medaglia, C. An innovative approach to control H. Pylori-induced persistent inflammation and colonization. Microorganisms 2020, 8, 1214. [CrossRef]

3. Cooke, C.L.; Huff, J.L.; Solnick, J.V. The role of genome diversity and immune evasion in persistent infection with Helicobacter pylori. FEMS Immunol. Med. Microbiol. 2005, 45, 11-23. [CrossRef]

4. Cullen, T.W.; Giles, D.K.; Wolf, L.N.; Ecobichon, C.; Boneca, I.G.; Trent, M.S. Helicobacter pylori versus the Host: Remodeling of the Bacterial Outer Membrane Is Required for Survival in the Gastric Mucosa. PLoS Pathog. 2011, 7, e1002454. [CrossRef]

5. Gebert, B.; Fischer, W.; Weiss, E.; Hoffmann, R.; Haas, R. Helicobacter pylori vacuolating cytotoxin inhibits T lymphocyte activation. Science 2003, 301, 1099-1102. [CrossRef]

6. Franceschi, F.; Gasbarrini, A.; Polyzos, S.A.; Kountouras, J. Extragastric Diseases and Helicobacter pylori. Helicobacter 2015, 20, 40-46. [CrossRef]

7. Eisenreich, W.; Rudel, T.; Heesemann, J.; Goebel, W. How viral and intracellular bacterial pathogens reprogram the metabolism of host cells to allow their intracellular replication. Front. Cell. Infect. Microbiol. 2019, 9, 42. [CrossRef]

8. Sancak, Y.; Bar-Peled, L.; Zoncu, R.; Markhard, A.L.; Nada, S.; Sabatini, D.M. Ragulator-rag complex targets mTORC1 to the lysosomal surface and is necessary for its activation by amino acids. Cell 2010, 141, 290-303. [CrossRef] [PubMed] 
9. Ansari, S.; Yamaoka, Y. Helicobacter pylori virulence factors exploiting gastric colonization and its pathogenicity. Toxins 2019, 11, 677. [CrossRef] [PubMed]

10. Kim, I.-J.; Lee, J.; Oh, S.J.; Chung, H.J.; Chen, J.; Blanke Correspondence, S.R. Helicobacter pylori Infection Modulates Host Cell Metabolism through VacA-Dependent Inhibition of mTORC1. Cell Host Microbe 2018, 23, 583-593. [CrossRef]

11. Lynch, C.J.; Adams, S.H. Branched-chain amino acids in metabolic signalling and insulin resistance. Nat. Rev. Endocrinol. 2014, 10, 723-736. [CrossRef]

12. Huang, X.W.; Luo, R.H.; Zhao, Q.; Shen, Z.Z.; Huang, L.L.; An, X.Y.; Zhao, L.J.; Wang, J.; Huang, Y.Z. Helicobacter pylori induces mitochondrial DNA mutation and reactive oxygen species level in AGS cells. Int. J. Med. Sci. 2011, 8, 56-67. [CrossRef]

13. White, J.R.; Winter, J.A.; Robinson, K. Differential inflammatory response to Helicobacter pylori infection: Etiology and clinical outcomes. J. Inflamm. Res. 2015, 8, 137-147.

14. White, P.J.; Newgard, C.B. Branched-chain amino acids in disease. Science 2019, 363, 582-583. [CrossRef]

15. Shao, D.; Villet, O.; Zhang, Z.; Choi, S.W.; Yan, J.; Ritterhoff, J.; Gu, H.; Djukovic, D.; Christodoulou, D.; Kolwicz, S.C.; et al. Glucose promotes cell growth by suppressing branched-chain amino acid degradation. Nat. Commun. 2018, 9, 1-17. [CrossRef]

16. Yilmaz, M.I.; Romano, M.; Basarali, M.K.; Elzagallaai, A.; Karaman, M.; Demir, Z.; Demir, M.F.; Akcay, F.; Seyrek, M.; Haksever, N.; et al. The Effect of Corrected Inflammation, Oxidative Stress and Endothelial Dysfunction on Fmd Levels in Patients with Selected Chronic Diseases: A Quasi-Experimental Study. Sci. Rep. 2020, 10, 9018. [CrossRef]

17. Lowell, B.B.; Shulman, G.I. Mitochondrial dysfunction and type 2 diabetes. Science 2005, 307, $384-387$. [CrossRef]

18. Sul, J.H.; Martin, L.S.; Eskin, E. Population structure in genetic studies: Confounding factors and mixed models. PLoS Genet. 2018, 14, e1007309. [CrossRef]

19. Allen, J.; Davey, H.M.; Broadhurst, D.; Heald, J.K.; Rowland, J.J.; Oliver, S.G.; Kell, D.B. High-throughput classification of yeast mutants for functional genomics using metabolic footprinting. Nat. Biotechnol. 2003, 21, 692-696. [CrossRef]

20. Shaham, O.; Slate, N.G.; Goldberger, O.; Xu, Q.; Ramanathan, A.; Souza, A.L.; Clish, C.B.; Sims, K.B.; Mootha, V.K. A plasma signature of human mitochondrial disease revealed through metabolic profiling of spent media from cultured muscle cells. Proc. Natl. Acad. Sci. USA 2010, 107, 1571-1575. [CrossRef]

21. Wang, T.J.; Larson, M.G.; Vasan, R.S.; Cheng, S.; Rhee, E.P.; McCabe, E.; Lewis, G.D.; Fox, C.S.; Jacques, P.F.; Fernandez, C.; et al. Metabolite profiles and the risk of developing diabetes. Nat. Med. 2011, 17, 448-453. [CrossRef]

22. Frühbeck, G. Obesity: Screening for the evident in obesity. Nat. Rev. Endocrinol. 2012, 8, 570-572. [CrossRef]

23. Newgard, C.B.; An, J.; Bain, J.R.; Muehlbauer, M.J.; Stevens, R.D.; Lien, L.F.; Haqq, A.M.; Shah, S.H.; Arlotto, M.; Slentz, C.A.; et al. A Branched-Chain Amino Acid-Related Metabolic Signature that Differentiates Obese and Lean Humans and Contributes to Insulin Resistance. Cell Metab. 2009, 9, 311-326. [CrossRef]

24. Yamakado, M.; Nagao, K.; Imaizumi, A.; Tani, M.; Toda, A.; Tanaka, T.; Jinzu, H.; Miyano, H.; Yamamoto, H.; Daimon, T.; et al. Plasma Free Amino Acid Profiles Predict Four-Year Risk of Developing Diabetes, Metabolic Syndrome, Dyslipidemia, and Hypertension in Japanese Population. Sci. Rep. 2015, 5, 11918. [CrossRef]

25. Holeček, M. Branched-chain amino acids in health and disease: Metabolism, alterations in blood plasma, and as supplements. Nutr. Metab. 2018, 15, 1-12. [CrossRef]

26. Toledo, J.B.; Arnold, M.; Kastenmüller, G.; Chang, R.; Baillie, R.A.; Han, X.; Thambisetty, M.; Tenenbaum, J.D.; Suhre, K.; Thompson, J.W.; et al. Metabolic network failures in Alzheimer's disease: A biochemical road map. Alzheimers Dement. 2017, 13, 965-984. [CrossRef]

27. Boado, R.J.; Li, J.Y.; Nagaya, M.; Zhang, C.; Pardridge, W.M. Selective expression of the large neutral amino acid transporter at the blood-brain barrier. Proc. Natl. Acad. Sci. USA 1999, 96, 12079-12084. [CrossRef]

28. Wang, R.; Reddy, P.H. Role of Glutamate and NMDA Receptors in Alzheimer's Disease. J. Alzheimers Dis. 2017, 57, 1041-1048. [CrossRef] [PubMed]

29. Song, M.K.; Bischoff, D.S.; Song, A.M.; Uyemura, K.; Yamaguchi, D.T. Metabolic relationship between diabetes and Alzheimer's Disease affected by Cyclo(His-Pro) plus zinc treatment. BBA Clin. 2017, 7, 41-54. [CrossRef] 
30. Ren, J.; Pulakat, L.; Whaley-Connell, A.; Sowers, J.R. Mitochondrial biogenesis in the metabolic syndrome and cardiovascular disease. J. Mol. Med. 2010, 88, 993-1001. [CrossRef] [PubMed]

31. Lamb, A.; Chen, L.F. Role of the Helicobacter pylori-Induced inflammatory response in the development of gastric cancer. J. Cell. Biochem. 2013, 114, 491-497. [CrossRef]

32. Koelman, L.; Pivovarova-Ramich, O.; Pfeiffer, A.F.H.; Grune, T.; Aleksandrova, K. Cytokines for evaluation of chronic inflammatory status in ageing research: Reliability and phenotypic characterisation. Immun. Ageing 2019, 16, 11. [CrossRef]

33. Heinz, S.; Freyberger, A.; Lawrenz, B.; Schladt, L.; Schmuck, G.; Ellinger-Ziegelbauer, H. Mechanistic Investigations of the Mitochondrial Complex i Inhibitor Rotenone in the Context of Pharmacological and Safety Evaluation. Sci. Rep. 2017, 7, 1-13. [CrossRef]

34. Xue, Z.; Zhao, H.; Zhu, R.; Chen, C.; Cao, H.; Han, J.; Han, S. On the use of abiotic sialic acids to attenuate cell inflammation. Sci. Rep. 2018, 8, 17320. [CrossRef]

35. Paglia, G.; Stocchero, M.; Cacciatore, S.; Lai, S.; Angel, P.; Alam, M.T.; Keller, M.; Ralser, M.; Astarita, G. Unbiased Metabolomic Investigation of Alzheimer's Disease Brain Points to Dysregulation of Mitochondrial Aspartate Metabolism. J. Proteome Res. 2016, 15, 608-618. [CrossRef] [PubMed]

36. Ivashkiv, L.B. The hypoxia-lactate axis tempers inflammation. Nat. Rev. Immunol. 2020, 20, 85-86. [CrossRef]

37. Newgard, C.B. Interplay between lipids and branched-chain amino acids in development of insulin resistance. Cell Metab. 2012, 15, 606-614. [CrossRef]

38. Laplante, M.; Sabatini, D.M. Regulation of $m T O R C 1$ and its impact on gene expression at a glance. J. Cell Sci. 2013, 126, 1713-1719. [CrossRef]

39. Bond, P. Regulation of $m$ TORC1 by growth factors, energy status, amino acids and mechanical stimuli at a glance. J. Int. Soc. Sports Nutr. 2016, 13, 8. [CrossRef]

40. Rabanal-Ruiz, Y.; Otten, E.G.; Korolchuk, V.I. mTORC1 as the main gateway to autophagy. Essays Biochem. 2017, 61, 565-584.

41. Matsunaga, S.; Nishiumi, S.; Tagawa, R.; Yoshida, M. Alterations in metabolic pathways in gastric epithelial cells infected with Helicobacter pylori. Microb. Pathog. 2018, 124, 122-129. [CrossRef]

42. Liu, L.; Luc, Y.; Martinez, J.; Bi, Y.; Lian, G.; Wang, T.; Milasta, S.; Wang, J.; Yang, M.; Liu, G.; et al. Proinflammatory signal suppresses proliferation and shifts macrophage metabolism from $M y c$-dependent to HIF1 $\alpha$-dependent. Proc. Natl. Acad. Sci. USA 2016, 113, 1564-1569. [CrossRef]

43. Sag, D.; Carling, D.; Stout, R.D.; Suttles, J. Adenosine 5'-Monophosphate-Activated Protein Kinase Promotes Macrophage Polarization to an Anti-Inflammatory Functional Phenotype. J. Immunol. 2008, 181, 8633-8641. [CrossRef]

44. Ricci, V. Relationship between vaca toxin and host cell autophagy in Helicobacter pylori infection of the human stomach: A few answers, Many questions. Toxins 2016, 8, 203. [CrossRef]

45. Spinelli, J.B.; Haigis, M.C. The multifaceted contributions of mitochondria to cellular metabolism. Nat. Cell Biol. 2018, 20, 745-754. [CrossRef]

46. D'Souza, G.; Waschina, S.; Pande, S.; Bohl, K.; Kaleta, C.; Kost, C. Less is more: Selective advantages can explain the prevalent loss of biosynthetic genes in bacteria. Evolution 2014, 68, 2559-2570. [CrossRef] [PubMed]

47. Bartfeld, S.; Bayram, T.; Van De Wetering, M.; Huch, M.; Begthel, H.; Kujala, P.; Vries, P.; Peters, R.; Hans, P.J.C. In vitro expansion of human gastric epithelial stem cells and their responses to bacterial infection. Gastroenterology 2015, 148, 126-136. [CrossRef]

48. Contaldi, F.; Capuano, F.; Fulgione, A.; Aiese Cigliano, R.; Sanseverino, W.; Iannelli, D.; Medaglia, C.; Capparelli, R. The hypothesis that Helicobacter pylori predisposes to Alzheimer's disease is biologically plausible. Sci. Rep. 2017, 7, 7817. [CrossRef]

49. Papaianni, M.; Paris, D.; Woo, S.L.; Fulgione, A.; Rigano, M.M.; Parrilli, E.; Tutino, M.L.; Marra, R.; Manganiello, G.; Casillo, A.; et al. Plant dynamic metabolic response to bacteriophage treatment after Xanthomonas campestris pv campestris infection. Front. Microbiol. 2020, 11, 732. [CrossRef]

50. Fulgione, A.; Papaianni, M.; Cuomo, P.; Paris, D.; Romano, M.; Tuccillo, C.; Palomba, L.; Medaglia, C.; De Seta, M.; Esposito, N.; et al. Interaction between MyD88, TIRAP and IL1RL1 against Helicobacter pylori infection. Sci. Rep. 2020, 10, 15831. [CrossRef] 
51. Papaianni, M.; Cuomo, P.; Fulgione, A.; Albanese, D.; Gallo, M.; Paris, D.; Motta, A.; Iannelli, D.; Capparelli, R. Bacteriophages Promote Metabolic Changes in Bacteria Biofilm. Microorganisms 2020, 8, 480. [CrossRef]

52. Sansone, C.; Nuzzo, G.; Galasso, C.; Casotti, R.; Fontana, A.; Romano, G.; Ianora, A. The Marine Dinoflagellate Alexandrium andersoni Induces Cell Death in Lung and Colorectal Tumor Cell Lines. Mar. Biotechnol. 2018, 20, 343-352. [CrossRef] [PubMed]

Publisher's Note: MDPI stays neutral with regard to jurisdictional claims in published maps and institutional affiliations.

(C) 2020 by the authors. Licensee MDPI, Basel, Switzerland. This article is an open access article distributed under the terms and conditions of the Creative Commons Attribution (CC BY) license (http://creativecommons.org/licenses/by/4.0/). 